Bryn Mawr College

Scholarship, Research, and Creative Work at Bryn Mawr College

1998

\title{
Monarchy and the Limits of Exemplarity in the Teatro Palaciego of Francisco Bances Candamo
}

Maria Cristina Quintero

Bryn Mawr College, mquinter@brynmawr.edu

Let us know how access to this document benefits you.

Follow this and additional works at: http://repository.brynmawr.edu/spanish_pubs

Part of the Spanish and Portuguese Language and Literature Commons

\section{Custom Citation}

Quintero, Maria Cristina. "Monarchy and the Limits of Exemplarity in the Teatro Palaciego of Francisco Bances Candamo." Hispanic Review 66, no. 3 (1998): 309-329.

This paper is posted at Scholarship, Research, and Creative Work at Bryn Mawr College. http://repository.brynmawr.edu/spanish_pubs/3

For more information, please contact repository@brynmawr.edu. 


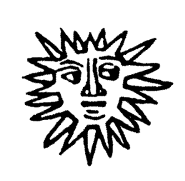

MONARCHY AND THE LIMITS OF EXEMPLARITY IN THE TEATRO PALACIEGO OF FRANCISCO BANCES CANDAMO

\author{
MaRÍa CRisTINA QUINTERo \\ Bryn Mawr College
}

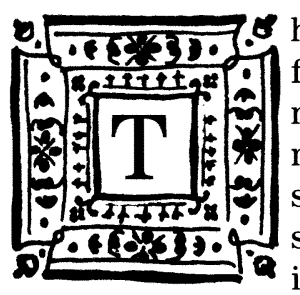

hroughout history, theater has provided a place for structuring the vision of a particular community. Because theater implies the collective remembrance and construction of certain common stories or myths, it often becomes the site of a society's self-imagining. The comedia that flourished in sixteenth- and seventeenth-century Spain was no exception. Whether invoking the protocols of courtship and honor or dramatizing the myth of Spain's imperial destiny, Golden Age theater became a mirror of a particular system of values and the locus for forging a communal, if imagined, identity.

With its dazzling pageantry and spectacle, the teatro palaciego of the Habsburg Court during the last part of the seventeenth century represents a peculiar manifestation of that society's self-fashioning. Although its immediate audience was an elite group, seemingly distant from the collective experience of the corrales, Court theater nevertheless became a politically charged manifestation of a society's assumptions about the structures that governed it. The confined space of the Court was, after all, a highly politicized community, one intensely self-conscious about the need to affirm its authority and control through the manipulation and preservation of certain symbols and myths of power. Theatrical spectacle provided the ideal vehicle for the ongoing process of constructing, mythifying, and mystifying absolutist power. 
Pedro Calderón de la Barca was clearly the most brilliant of Court dramatists. As Margaret Greer has shown, we discover in his plays the most effective reenactment of the myths of power and kingship. ${ }^{1}$ The present study deals with another remarkable playwright who flourished at the end of the Golden Age. This was Francisco Bances Candamo (1662-1704) who, like Calderón, took advantage of the conditions of performance in the palace theater in order to forge a political/didactic drama. ${ }^{2}$ His plays provide a powerful paradigm for the study of the interplay of politics, history, myth, and theater during the late Spanish Baroque.

Working under the patronage of the Crown, like Calderón before him, Bances found himself a participant in the political community of the Court not just as propagandist but as commentator and preceptor to the Prince. Named Court playwright by Charles II (an honor which, incidentally, Calderón never officially held), Bances saw his privileged position as comprising nothing less than a civic obligation, an invaluable opportunity to educate Charles in the art of kingship. In his important theoretical treatise on drama, Theatro de los theatros de los passados y presentes siglos, Bances states:

me hallo elegido de su Magestad por su Real decreto para escriuir vnicamente sus festejos, y con renta asignada por ello, he juzgado tocarme por muchos títulos estudiar ex profeso quanto pudiese conducir a hacer arte áulica y pollítica la de festejar a tan gran Rei, cuios oídos se me entregan aquellas tres horas, siendo ésta vna de las maiores confianzas que se pueden hacer de vna doctrina.

In this passage, as in others, Bances recognizes the need to negotiate the narrow straits between adulation (festejar) and counsel (doctrina), between panegyric and critique. Elsewhere in the treatise, Bances proposes theater as an extension of political thought, an acting out of contemporary theories of state. As Juan Sánchez Belén has demonstrated, Bances had a thorough knowledge of the treatises

\footnotetext{
${ }^{1}$ See Greer's The Play of Power and the introduction to her edition of Calderón's La estatua de Prometeo.

${ }^{2}$ Bances Candamo has received steady critical attention over the last decade. Particular credit must be given to Ignacio Arellano's fine articles and editions. Other recent articles have been writen by Santiago García Castañón and Juan Sánchez Belén. All of these owe a great debt to Duncan Moir who, in the introduction to his excellent edition of Bances's Theatro de los Theatros, provides the first serious study of this previously neglected playwright.
} 
written by sixteenth- and seventeenth-century political theorists, from Diego de Saavedra Fajardo to lesser-known arbitristas such as the Marqués de Villena, Alvarez Osorio, and Baños de Velasco. Direct correspondences may be found between the lessons in the art of governing imparted in the dialogue of Bances' plays and the ideas espoused by these writers. Bances, himself the author of two political treatises, can be studied, then, not just as a dramatist belonging to the Calderonian school, but also as a minor theorist working within the tradition of the arbitristas. ${ }^{3}$ The treatises written by the arbitristas not only constitute a genre that falls between historiography and literature, but also represent a corpus of political thought that complements the aesthetics of monarchy incorporated into the theater of the Baroque.

One of the major concerns of Saavedra Fajardo and other theorists was the need to address the crisis of the monarchy directly and provide an inducement to action and change. The last decades of the seventeenth century proved an extraordinarily vulnerable time for the Spanish monarchy and empire, and a particular challenge to the arbitristas. This vulnerability was embodied in the curious figure of the king, Charles II. Plagued by serious physical and mental infirmities, Charles represented not only the demise of the Habsburg dynasty, but also a particularly debased image of the monarchy within a society keenly vigilant of its images and its emblems. There is ample evidence suggesting that Charles was something of an embarrassment at the Court and abroad. The papal nuncio described the twentyfive-year-old king in a letter:

The king is short rather than tall; frail . . . his face on the whole is ugly; he has a long neck, a broad face and chin, with the typical Habsburg lower lip. . . . He cannot stand upright except when walking, unless he leans against a wall, a table or somebody else. He is as weak in body as in mind. Now and then he gives signs of intelligence, memory and a certain liveliness, but not at present; usually he shows himself slow and indifferent, torpid and indolent, and seems to be stupefied. One can do with him what one wishes because he lacks his own will. (Kamen 21)

Indeed, Charles was the manifest antithesis of the ideal prince collectively portrayed by the humanist tradition of exemplarity later

${ }^{3}$ These two treatises by Bances-Avisos de la Monarchía Española and Chronicón del Rey don Carlos Segundo de España - have apparently been lost. Bances refers to them in his Theatro de los theatros. 
taken up by the political theorists. ${ }^{4}$ In body and mind, he contradicted the heroic ethos that had shaped the image of the Renaissance prince. Juan de Zabaleta, an author and playwright who influenced Bances, offers in his El Emperador Commodo. Historia discursiva según el texto de Herodiano (1672) a portrait of the ideal king. We find in this treatise a discussion of the relationship between authority and the physical appearance of the king:

Para la primera vista muy buena recomendación es la hermosura. En los Príncipes siempre es muy buena, porque es autoridad siempre. El príncipe de persona mal formada, con la presencia da que notar, y en quitándose el peligro, da que reir. Todos piensan que pueden burlarse de quien creen que se burla la naturaleza.

Of interest here is the correspondence established between physical appearance and authority. Seemingly mocked by nature, Charles-a "príncipe de persona mal formada," as even his most flattering portraits reveal-visibly lacked authority and the ability to command respect. Indeed, the king became the target of virulent criticism, as indicated by the numerous anonymous poems and pasquines that appeared throughout the years of his reign, ridiculing his unsightly figure and his incapacity to govern effectively. It is not surprising that, according to J. Cejador y Frauca, "la sátira, con vis cómica popular, es el único género que señorea en la época de Carlos II. Mayormente la sátira política se ceba en los ministros, en la Reina, en el mismo Rey" (qtd. in Martín Vega 91). ${ }^{5}$ The topic of greatest concern at the Court, and therefore the most common target for political satire, was the probability that the king would be unable to provide an heir to the throne. Public opinion was aggressively vigilant of the sexual politics that were being played out to maintain the dynasty. When Charles II married Marie Louise of Orléans, her ability to provide an heir became a public matter of concern, as indicated by the following popular quatrain:

Parid, bella flor de lis que en aflicción tan extraña si parís, parís a España

\footnotetext{
${ }^{4}$ For the Renaissance concept and use of exemplarity, see Timothy Hampton.

${ }^{5}$ Martín Vega does not concur entirely with Cejador y Frauca's opinion: "Conviene matizar que, al igual que abundan las críticas al Gobierno de la Nación, también existe un elevado número de folletos celebrando las sucesivas recuperaciones del Rey" (9192).
} 
si no parís, a París. (Kamen 373)

The last line slyly suggests not only that the queen should be returned to her native country if she fails to produce an heir, it also expresses the prevalent fear that Spain itself would fall prey to France should there be no successor. When Charles's second wife, Mariana of Neuburg, also failed to get pregnant, rumors of the king's impotence became impossible to quell, giving rise to great political unrest. The diminished possibility of inherited succession exacerbated the already critical problem Charles had in establishing any real authority and, more seriously, inspired a complex and dangerous power play on the part of European monarchs-especially Louis XIV - that threatened the autonomy of the Peninsula. The Spanish succession became the burning topic that would dominate European politics throughout the reign of the unfortunate king. ${ }^{6}$

Given the dire political circumstances, the didactic and propagandist potential of Court theater during Charles's reign acquired special significance. The teatro palaciego became for Bances not only a convenient medium to impart to the weak king some measure of guidance and insight in the art of governing, but also a vehicle to construct and promote an idealized image of the monarchy. In the throes of moral and intellectual bankruptcy, the actual monarchy in Spain suffered from clear degeneracy. Thus, Bances, like Calderón before him, found himself aesthetically supplementing an inadequate reality in order to preserve a public myth of power. During the reign of Charles II, the institution of kingship in the Spanish Empire depended more than ever on pageantry, rituals, and theatricality for its legitimation. Theater, as it has so often in its history, served the function of political memory, rescuing a system of symbols and power, and also reminding the Court audience of the need to preserve, strengthen, and elaborate those very symbols and myths.

There is every indication that Bances was a loyal courtier who was grateful to Charles for the privilege bestowed upon him. It would be misleading, therefore, to attribute to Bances a strongly parodic or intentionally subversive stance vis à vis the king. For someone like Bances, someone who clearly benefited from the patronage of the king, the monarchy was the only imaginable political system. Like most of his contemporaries, he accepted the idea of the divine nature

\footnotetext{
${ }^{6}$ See Henry Kamen and John Lynch on the question of the Spanish succession.
} 
of kingship. In Por su rey y por su dama, for example, we have the following description of the monarchy:

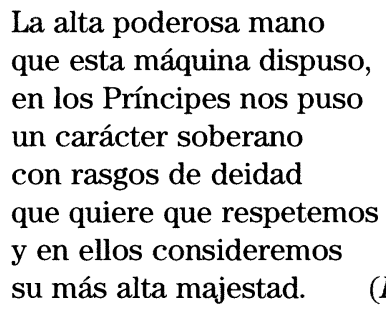

La alta poderosa mano que esta máquina dispuso, en los Príncipes nos puso un carácter soberano con rasgos de deidad que quiere que respetemos y en ellos consideremos su más alta majestad.

(Pc I: 455-56)

Nevertheless, one cannot help but be surprised by the insistence and daring with which Bances dramatized the vulnerability of the actual Crown in his comedias. The playwright attempted to influence Charles on a number of issues popular with arbitristas - for example, the over-dependence on validos - but most prominently, on the controversial issue of the succession. Indeed, Bances makes the succession the central subject of his most important plays at a time when the king had forbidden any mention of the topic. Of the twenty odd plays that he composed, three are of particular interest: El esclavo en grillos de oro, Cómo se curan los celos, and La piedra filosofal. ${ }^{7}$ In these plays, Bances manipulates the topic of the succession by taking exemplars from history, legend, or myth, thereby enacting for Charles illustrious genealogies of the Spanish throne. Like the humanists and the arbitristas, Bances makes exemplarity the cornerstone for fashioning his political message. The plays engage the past through the dramatization of historical, poetic, and mythic figures in order to forge an idealized image of the monarchy and impress upon the king the importance of providing for the continuation of power.

The present study will deal primarily with La piedra filosofal. In order to better understand this original and daring work, however, we will begin with a brief consideration of El esclavo en grillos de oro and Cómo se curan los celos. El esclavo en grillos de oro has been considered Bances' masterpiece. The play, written in 1692 and performed in the Salón Dorado of the Royal Palace on November 20 of that year, dramatizes a fictional struggle for power during the reign

\footnotetext{
${ }^{7}$ Duncan Moir, in the prologue to his edition of Theatro de los theatros, was the first to privilege these three plays as the most politically charged, and other critics have followed suit. Ignacio Arellano, however, questions the notion of a political trilogy.
} 
of the Roman emperor Trajan. Although not strictly a historical play, El esclavo engages Roman history - readily accepted by the seventeenth-century audience as part of its national historical consciousness - and offers an exploration of the workings and limits of exemplarity. The belief that Trajan was a "Spanish" emperor, and therefore a forebear of the present monarch, provides Bances with an appropriate historical (but conveniently distant) backdrop for the unfolding of his political fable. According to Langdon-Davies, palace lore promoted the association of Charles with Trajan because they had both been born on the sixth day of the month (15). The association between the Roman emperor and the actual king helped Bances to enact for his audience a genealogy of power and princely conduct based on quasi-historical events.

El esclavo is paradigmatic of Bances' use of history and exemplarity. History was at the center of numerous political treatises dealing with the education of the king. Saavedra Fajardo had said in his Idea de un príncipe político cristiano that "la historia es maestra de la verdadera política, y quien mejor enseñará a reinar al príncipe, porque en ella está presente la experiencia de todos los gobiernos pasados" (I: $55-56$ ). This idea is a continuation of the humanist emphasis on exemplarity which entailed the interpretation of past events and their application to practical political action in the present. In addition, as Nancy Struever and Timothy Hampton have studied, history was viewed during the European Renaissance as the understanding of past experience in terms of future choices. Bances' play presents a perfect paradigm for this Janus-like view of history. By presenting El esclavo at the Court and exploiting the double theatrical perspective (the stage and the throne), the play visually established a continuity of Roman greatness in the Spanish present while attempting to influence future political action.

In keeping with the humanist pedagogical ideal promoted by Erasmus, among others, playwrights such as Calderón and Bances adopt the role of intermediaries between past and present. Thus, in Bances' play, the relationship between the staged action and the political situation in the palace would have exploited historical synchronicity by incorporating contemporary issues or concerns into the performance. Since El esclavo deals openly with the question of succession, the future of the Crown is aggressively engaged as a topic for meditation and consideration. 
The play centers around the presentation of Trajan as the ideal monarch who is himself a competent reader of history and heeds the examples of the past. At one point in El esclavo, Trajan states: "en materias de Estado/Discípulos de sus padres/Han de ser los soberanos." More directly, in the third act, Trajan says:

Porque el reinar necesita

De tan grandes experiencias

Que en una vida adquirirlas

No es posible; $y$ estudiando

Todas las cosas antiguas,

Pocas horas de memoria

Son muchos siglos de vida.

(197; emphasis added)

In his speech, Trajan reiterates the gospel of exemplarity, i.e. the importance of interpreting the past in order to influence present and future action. Furthermore, Trajan is an exemplary ruler precisely because he has diligently pondered the issue of succession. He has carefully groomed his nephew Hadrian for the task of taking over the throne. His prudent plans, however, are put to a test when he discovers a conspiracy led by a consul named Obinio Camilo to take over the throne. The play presents both positive and negative examples of leadership in El esclavo: Obinio Camilo enacts the conflict between public responsibility and private desires, with the latter ultimately gaining the upper hand; Trajan's wisdom and self-sacrifice, on the other hand, provide a maximum model of comportment for a monarch - a model that will be followed by his worthy successor, Hadrian. In spite of the happy ending with the rightful heir inheriting the throne, the staging of a conspiracy within the broader setting of the Habsburg Court would implicitly call into question the authority of the king in the audience by suggesting that his throne, like that of his dramatic counterpart, is potentially under siege. Conspiracies provide the central fable in the vast majority of historical and political dramas written during the Renaissance in Europe (Lindenberger 30). A subtle artist such as Bances would have been conscious of the political and dramatic impact of this motif and clearly engaged it as a way of alerting the monarch to the chaotic political situation. At another level, within the extended theatrical space of the Court, the presentation of an idealized Trajan underscores the limits and dangers of exemplarity as manipulated by Bances. The contrast between Trajan's greatness and the pathetic reality embodied by Charles must 
have produced a particularly violent instance of dramatic irony that could not have been lost on the Court audience. The play is indeed fraught with this irony. Although order is restored at the end of the play, the peaceful solution is undermined by the political passions and destabilizing actions that have been presented throughout. More to the point, El esclavo presents an exaltation of kingship and a vivid articulation of the precarious nature of power and authority as manifested in the actual king and his disastrous reign.

The second play in the trilogy, Cómo se curan los celos (1692), represents a unique reworking of Ariosto's Orlando Furioso. The play, which has survived only as a zarzuela, is the most oblique in its commentary on the current political situation. The central figure of Cómo se curan los celos is Orlando, whose obsession with Angélica becomes a threat to the state because it weakens the political alliance between Orlando and his uncle, Charlemagne. The cure for jealousy announced in the title is time, which allows Orlando to forget his illfated love and reintegrate himself into the political and military arenas of the Empire. Again, the crucial political relationship is between an uncle and a nephew, the latter presented implicitly as the heir to the former. Lessons in statesmanship abound in this play as well, although they are overshadowed by the politically charged elements appearing in the loa that introduces the play. ${ }^{8}$ The performance of Cómo se curan los celos was prepared specifically "en celebridad del felice nombre del rey," and Bances uses the pretext of the king's name-day in order to elaborate a political allegory in the loa. Each letter in the name "CARLOS" becomes an excuse for invoking an onomastic genealogy, as historical monarchs whose names begin with the six letters are evoked. $\mathrm{C}$ is thus associated with Charles V and Charlemagne; A with Alarico and Amalarico; $\mathrm{R}$ with Recardos and Ramiro; L with Ludovico and Leopold, O with Ordoños; S with Sancho and Segismundo, etc. By associating the king's name with eminent ancestors, many of them specifically "Spanish" Visigothic kings or members of the Habsburg house, Bances dramatizes a symbolic heritage and impresses upon his royal audience the importance of maintaining the integrity of its symbols. In this manner, the name "CARLOS" represents a single, easily apprehensible sign which condenses within it the entire history of the ancestors' deeds and their

\footnotetext{
${ }^{8}$ See Arellano's introduction to his edition of Cómo se curan los celos for a more detailed study of the play.
} 
importance as exemplars. The name becomes an emblem of the monarchy, an emblem of power, as the allegorical character, la Noticia, makes clear:

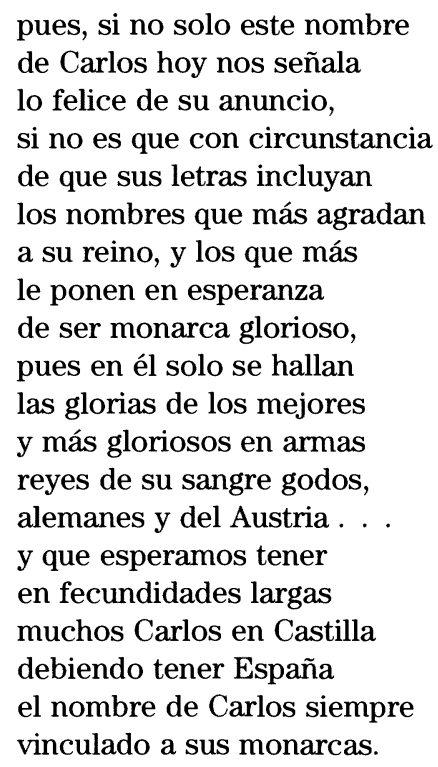

The purpose of the loa is not only to evoke a glorious monarchical past, but also to emphasize the need for an equally glorious future. The audience, particularly the royal couple, were expected to extract from the names and the allegorical pageant on stage a lesson on the importance of strengthening the monarchy and recognizing the models by which they are to measure their own actions. In addition, there are direct references to the question of the succession. At one point, for example, Queen Mariana of Neuberg (Charles' second wife) is directly addressed:

$$
\begin{aligned}
& \text { Y Mariana divina, } \\
& \text { a España alegre } \\
& \text { le duplique este nombre } \\
& \text { en descendientes. }
\end{aligned}
$$

By simultaneously evoking the glorious monarchical past represented by those illustrious names and urging the continuation of the line, the king is reminded in a none-too-subtle manner of his political responsibilities: "y que esperamos tener en fecundidades largas muchos 
Carlos en Castilla." Ignacio Arellano has suggested that here, Bances may be specifically promoting the Archduke Charles of Austria (the second son of Emperor Leopold I) as successor, since he conveniently provided an obvious continuation of the prestige of this particular royal name (Cómo se curan 48).

In El esclavo, Bances presents a quasi-historical genealogy by reminding his noble audience of the glorious Roman past to which all Spaniards felt heir. The loa of Cómo se curan los celos enacts an onomastic genealogy which rescues the memory of illustrious ancestors contained within the name of the present king. In the process, Bances emphasizes the importance of maintaining the symbols of power and the need for stability and continuity of royal power. In the third play of the so-called trilogy, La piedra filosofal (1693), Bances explores the fluid boundary between myth and history by providing an apocryphal but equally illustrious genealogy. La piedra filosofal is a daring political work that eschews well-known classical myths and creates new exemplary archetypes that would have particular relevance to Bances' courtly audience. The playwright seems to have felt the need to construct a new, specifically Hispanic myth at a time when the future of the Habsburg dynasty in Spain was gravely compromised. In La piedra filosofal, he elaborates a mythical story about the beginning of royal power in Spain. Set in pre-Roman, pre-historical time, La piedra filosofal tells the story of a king named Hispán who, finding himself without a male heir, must choose between three suitors for the hand of his daughter, Iberia. The heir who is finally chosen is Hispalo, who turns out to be Hispán's nephew, echoing the blood-ties between Trajan and Hadrian in El esclavo and Charlemagne and Orlando in Cómo se curan los celos.

The three main figures in La piedra filosofal, Hispán, Iberia, and Hispalo, onomastically evoke the political and geographical entity that would, in "historical" time, be known as Spain. Hispán is addressed as he "de quien toma el nombre todo tu Reino,/Porque hechura de tu mano/se confiese así tu Imperio" (252). Furthermore, this apocryphal monarch is a nephew of Hercules, who was traditionally invoked as the mythical founder of Spain, as Iberia states:

Hoy, que a Hércules nuestro tío, griego blasón, y el primero que a esta inmensa monarquía convirtió el bastón en cetro como a nuevo Dios de España 
añadido al firmamento, donde él puso las columnas hemos erigido un templo.

Legend had it that Hercules had erected the Pillars of Hercules at the Atlantic entrance to the Mediterranean. The pillars have been identified with the rocks of Calpe (Gibraltar) and Abyea (Ceuta), which flank the Straits of Gibraltar. Furthermore, the figure of Hercules, as Brown and Elliott have noted, held a prominent place in the iconography of power in the Habsburg monarchy (156-61). According to Greer, the chronicler Fernández de Heredia identifies Hercules as the first king of Spain, and establishes a direct line between Hercules and Charles II (Play of Power 161). Brown and Elliot describe the Hall of Realms in the Palace of Buen Retiro, with its ten canvases of Hercules' labors, which graphically associate them with the glorious deeds of Spanish kings and with the escutcheons of the twenty-four kingdoms of the Spanish monarchy (188).

The fashioning of a new myth of monarchical power required the use of archetypal figures, their association with an established icon of might (Hercules), and an indefinite temporal setting of the play. Within the mythical ambiance of La piedra, nevertheless, the history of Spain's imperial designs is invoked time and time again. Rocas, the philosopher/magician who had been Hispalo's tutor and is now Hispán's counselor, possesses both a backwards and a forward knowledge of history. He states at one point: "todas las edades vivo" (256). There is a manifest desire to dramatize the timelessness of virtues and values associated with the monarchy, their permanence regardless of temporal circumstances. The manipulation of ahistorical time also corresponds to a traditional Christian scheme in which persons and events are not unique in human history, but rather exemplary (Lindenberger 110). The characters are, then, prefigurations of future Spanish monarchs. By placing the action in an ahistorical time that replicates a traditional Christian conception of time, Bances attempts to make the action even more paradigmatic, the characters more exemplary. In addition, by establishing clear parallels between the main plot of the play, the search for a suitable husband for Iberia, and the actual predicament in the Habsburg Court, Bances daringly exhorts his royal audience to action. The atemporal mythic events depicted in the play achieve their maximum significance only in relationship with the actual temporal historical situation of the Court. The overt concern with the thorny problem of finding an heir to the throne is 
established in the very first scene when Rocas states: "De los reyes españoles / quise investigar, atento, / la sucesión" (230). The presentation of the theme of succession that follows, however, is complicated and ambiguous, as are the figures claiming the audience's attention as exemplars.

King Hispán is indeed obsessed with finding the right husband for his daughter Iberia, thus ensuring the stability of his land:

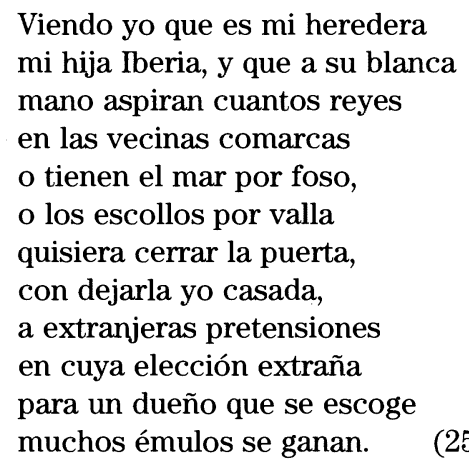

The speech underscores the striking parallels between the play's action and the actual political situation in the Habsburg Court where the choosing of any successor ("elección extraña") could have the effect of creating enemies ("émulos"). Hispán continues:

Con príncipes extranjeros
quiero excusar alianzas,
que al límite de mi Imperio
término mayor añadan;
que tienen las Monarquías
cierto coto y cierta raya,
hasta donde a mantenerlas
de un rey la prudencia basta,
y de un poder el dominio;
pero si esta línea pasan,
luego a declinar empiezan,
porque, en fin, es limitada
toda humana providencia

$(257-58)$

Although Hispán recognizes the need to choose a successor to avoid wars and stem his empire's decline, he is also reticent in handing over his power and is too hesitant in making a decision. He jealously 
guards his supremacy to the point of showing himself shockingly ungrateful when Hispalo saves his life:

no sé quién es, y es gran yerro
que me deje obligar tanto,
porque un beneficio inmenso
estrechándome la paga,
me limita lo supremo.

Ingratitude on the part of monarchs was a recurring subject in the treatises written by the arbitristas. This scene may be interpreted as a reprimand to the real king, who enraged even his supporters by his capriciousness and by often forgetting promises he had made. More significantly, Hispán's indecisiveness is also reminiscent of the historical Charles, whose mental deficiencies, according to Kamen, prevented him from making a single major decision throughout his reign (22).

If Hispán is the dramatization of the origins of monarchical power, the beautiful Iberia is the personification of Spain itself. By extension, Iberia's suitors may be seen as the theatrical representations of the pretenders to the Spanish throne, although there seems to be no exact correspondence between the dramatic characters of the play and the real-life pretenders to the throne..$^{9}$ Iberia is portrayed as a diplomat who understands the need for maintaining peace. She will not permit her suitors to fight over her and, instead, cleverly channels their competitiveness into civic projects that would benefit her people. At one point, after the suitors have started duelling in her presence, Iberia directly chastises her father for hesitating in choosing a successor and thereby placing her in a precarious situation:

Esto es, señor, haber puesto
(quizá inadvertidamente)
a competencias mi mano,
en efecto que indecentes
quieren con sus arrogancias
disuadir mis altiveces
siendo tu razón de estado
quien me obliga a que sujete
con dos lazos al laurel,
y a la coyunda las sienes.

${ }^{9}$ The pretenders were Victor Amadeus II of Savoy, Joseph Ferdinand of Bavaria, the Archduke Charles, Pedro II of Portugal, and Philip of Anjou. 
At a time when Louis XIV of France had launched a vigorous campaign to influence the succession in Spain and other European powers awaited vigilantly a decision, these words constitute a plea to the actual king to avoid impending wars over the succession by choosing an heir immediately. Iberia, nevertheless, is also a contradictory character that embodies both positive and negative characteristics. For one thing, she is an allegorical mujer esquiva, an imperious and disdainful princess, cautious of giving even the slightest appearance of favoring any of the pretendientes. At one level, Iberia is meant to exemplify autodominio, a virtue emphasized time and time again by political theorists and playwrights in their presentation of royal personages. Nevertheless, in the portrayal of Iberia, Bances seems to be saying that while Spain should be careful and jealous of her sovereignty (i.e., her honor), over-cautiousness could result in further endangering her position.

Hispalo, who is eventually chosen as heir, is also a complex character despite his bravery, nobility, and profound sense of justice. The latter manifests itself most remarkably in the scene when he risks earning the displeasure of the king by opposing an arbitrary and unjust order to forcibly arrest Rocas:

SoldADO: ¿Pues vos queréis oponeros

así a un precepto del Rey?

HisPalo: No me opongo yo al precepto

del Rey, ni a su ejecución, sino en ella al modo vuestro; yo le llevaré, dejadle.

In this passage, criticism of the whims and arbitrariness of power is skillfully deflected from the figure of the king by focusing on the underlings who implement the monarch's orders.

The most significant portion of the play involves Hispalo, as he finds himself the unwitting protagonist in an experiment in the art of government. Before choosing him as his successor, King Hispán enlists Rocas' help in determining whether Hispalo will prove a worthy monarch.

algo mi elección se ataja,

hasta ver en la experiencia,

si es que sus virtudes pasan

de prendas a caballero

a excelencias de monarca. . . . 


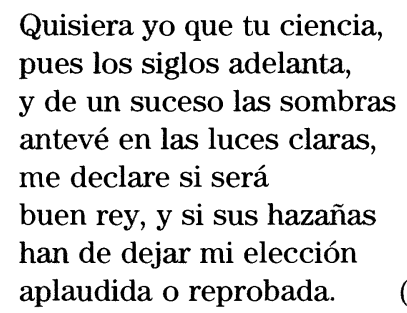

This situation closely parallels Basilio's dilemma in Calderón's $L a$ vida es sueño. After consulting the stars, Rocas discovers that Hispán's successor will be the instrument of his (Rocas') own death. Nevertheless, he decides to test the young man, echoing the action and message in Calderón's famous play:

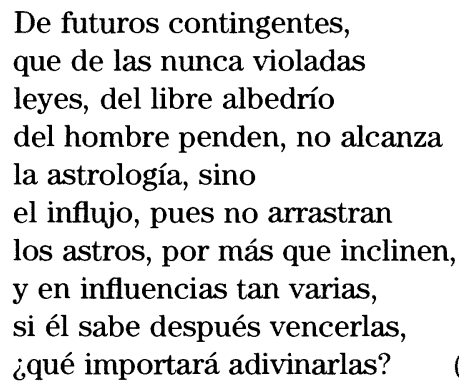

Rocas (who is also a magician) conjures an elaborate scene staged for the unsuspecting Hispalo in which he is chosen as Iberia's husband. Hispalo promises to remember always the favors bestowed on him and to never take arms against either the king or his advisor. Nevertheless, once Hispalo is named heir to the throne, a conspiracy allegedly spearheaded by Rocas is revealed; and Hispalo, forgetting his promise, condemns Rocas to death. At that point, the enchantment disappears and Hispalo finds himself as he was before, a poor competitor for Iberia's hand with little prospect of being accepted. No longer sure of what is real and what is illusion, he behaves erratically and is taken by the other characters to be either bewitched or a madman, echoing the behavior of his divine forebear, Hercules, whose legend also involved bouts of madness and violence. Bances deftly takes up again the Hercules motif, but in a different register, transforming the icon of monarchical power into a negative exemplar.

It is clear that Bances' intention in writing La piedra was to further the iconography of the monarchy through the tripartite portrayal 
of the archetypal Hispán, Iberia, and Hispalo. At the same time, their exemplarity is undercut by their flawed character and actions. The portrayal of monarchy in this play is, therefore, contradictory at best; and at times, almost reckless. ${ }^{10}$ It was particularly audacious of Bances to incorporate the scenes of Hispalo's insanity or bewitchment. The king to whom the play was directed was himself taken by many to be both mad and bewitched, as indicated by his epithet, "el hechizado." Also remarkable is Hispán's advice to Hispalo after one of his "mad" episodes:

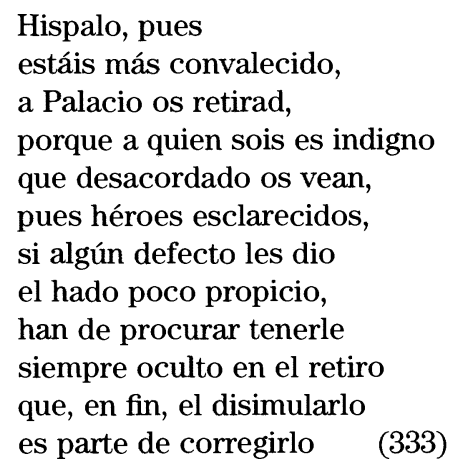

One can only imagine the discomfort, and perhaps indignation, of the palace audience at being reminded of the erratic behavior of their own monarch-behavior that often resulted in Charles being sequestered in El Retiro. The playwright tries to mitigate this unflattering portrayal by alternating the character's mad (descordado) behavior with clear signs of cordura and bravery. The suggestion is also made that Hispalo's madness is understandable given the unjust treatment at the hands of Hispán, Iberia, and especially Rocas. However, the audience's association between the undignified behavior of the dramatic character and that of the actual king must have been inevitable.

Whether intended by the playwright or not, the mythic genealogy proposed in La piedra clearly contains the roots of subversiveness. Judith Shklar and Margaret Greer have both pointed out that the search for ancestors and for origins is often a typical form

${ }^{10}$ Bances disappeared from the Court shortly after the play was produced and died only a few months later, the possible victim of poisoning. There were suspicions that his daring portrayal of aspects of the monarchy might have inspired the enmity of others in the Court. 
of questioning and condemning the established order. Bances' genealogy is potentially subversive because it provides ambiguous symbols of power: Hispalo is mad, Hispán is ungrateful and hesitant, Iberia is obsessively cautious, and the wise Rocas is overzealous. Also dangerous is the presentation of the alleged conspiracy perpetrated by Rocas. As with the conspiracy in El esclavo, these scenes present the monarchy as an institution vulnerable from within and without.

Like Calderón before him, Bances used all the artistic resources available to him - the technical advances, complex artistic codes of the theater, and the poetic discourse of his time-to forge a complex, polyvalent spectacle. The stage directions in La piedra abound in references to elaborate scenery, music, dance, theatrical lighting, and numerous other special effects: "Salen cuatro damas y cuatro galanes con hachas y mascarillas danzando . . ." (296) or "Suena terremoto y los que están en el teatro, unos se bandean y otros vuelan . . ." (302). The emphasis is on theatricality and spectacle as the playwright puts all the illusionist tricks of his craft at the service of an allegorical representation of a political situation. At the beginning of the second act, for example, the stage direction indicates the following: "Salen con Iberia damas y la Música y los tres Príncipes están por diferentes paños, como acechando" (269). In this scene, the playwright kinetically portrays Spain's predicament of being besieged on all sides by foreign pretenders to the throne. In palace theater of this kind, characterization and plot development became incidental. Beyond the brilliant display of spectacle, there is throughout a self-conscious concern with the techniques and thematics of illusion. ${ }^{11}$ Hispalo is made to believe that he is the chosen successor through an elaborate enchantment complete with music, pageantry, thunder, and conflagrations. When this elaborate play-within-the-play disappears, Rocas tells Hispalo:

Cuanto has visto . . .
ha sido apariencia
desde el fuego hasta las bodas;
cuantas personas diversas
has visto fueron fingidas,
Rey, príncipes y princesa

\footnotetext{
${ }^{11}$ See Anthony Cascardi, The Theater of Illusion.
} 
In this complex and no doubt controversial scene, kingly power is unmasked as illusory and temporary, something that can be readily taken away.

There is an intricate theatrical transaction at work in Bances' dramaturgy as he establishes reciprocity between the fiction of his plays and the actual political situation. We discover a triple performance in action: the play itself, the plays-within-the-plays, and the larger (and equally theatrical) spectacle of the Court. At one level, the pageantry, allegorical characters, and staging are all seemingly orchestrated to celebrate monarchical power and continuity. At the same time, this is a theater of self-scrutiny, as the king is invited to view the figures of authority as both examples and versions of himself. The drama of selfapprehension-aborted though it may have been, given the king's mental infirmities-is in turn observed by the larger audience of the Court. The plays represent, therefore, studies in comparative leadership not only among the characters in the spectacle (e.g., Trajan and Hadrian in El esclavo, Hispán and Hispalo in La piedra), but also between the dramatized monarchs and their counterpart in the audience, Charles II. The result, as has been suggested before, must have been fraught with irony; and indeed, dramatic irony provides both structure and value in the elaborate mises-en-scene. Ultimately, what is dramatized is the chasm between historic or mythic models of authority and the pathetic reality of the actual king. Through the ironic split between staged majesty and flawed reality, Bances simultaneously reinforces a collective myth of power, while at the same time vividly dramatizing the fragility of the monarchy in its actual state. Certain critics, Ignacio Arellano most prominently, have resisted seeing any kind of critical intent in Bances' portrayal of the monarchy. The virtues of royal power and its continuity, they claim, are enthusiastically affirmed at the end of the plays with the selection of the best successor to the throne. ${ }^{12}$ While this is true, there is no doubt that ambivalence is a built-in condition of the political message of his plays. Indeed, what is affirmed at the end (an exalted iconography of the monarchy) is powerfully at

${ }^{12}$ Although not dealing with any particular play in detail, a recent article by Santiago García Castañón also presents the probability of a critical stance on Bances Candamo's part. He states in response to Arellano's position: "En opinión de Ignacio Arellano . . . no hay en las obras de nuestro dramaturgo una crítica política dirigida abiertamente contra Carlos II, sino más bien un ataque a la moral de su tiempo, pero-añado yoese ataque a la moral puede llegar a afectar ocasionalmente hasta al mismo rey, con lo cual el argumento de Arellano no siempre puede defenderse con eficacia" (233). 
odds with the instability that is being shown all along, especially within the extended theatrical space of the Court.

Bances' plays have, no doubt, suffered from the same prejudice accorded Calderón's palace comedies, particularly the mythological plays. Critics have been too quick to dismiss these plays as self-serving, sycophantic exercises, amounting to little more than monarchist propaganda. A close analysis of these plays makes it difficult to accept this limiting view of the teatro palaciego. There is in Bances, as in Calderón, a certain melancholy in their enactment of Renaissance notions of princely exemplarity. The representation of exemplary models of the monarchy should have led ideally to the proper interpretation, the necessary first step in effecting action and change. Sadly, however, the most important reader and spectator-the king himself-did not possess the mental capacity to properly interpret Bances' spectacle of exemplarity. At a time of diminished possibilities for real political action, Bances-like his own exemplar, Calderón de la Barca-made the teatro palaciego the site for negotiating commentary and criticism of current policies in the hope (however vague) of influencing the king. Furthermore, in their hands, the monarchy itself becomes an aesthetic construct, an artefact to compensate for the deficient reality. Francisco Bances Candamo is a playwright who deserves to be incorporated into our working canon of Golden Age theater. His plays offer a particularly eloquent mediation on the discourse of power and the limits of exemplarity in seventeenth-century Spain, at a moment of dire instability and transition.

\section{WORKS CITED}

Arellano, Ignacio. "Teoría dramática y práctica teatral. Sobre el teatro áulico y político de Bances Candamo." Criticón 42 (1988): 169-93. Bances Candamo, Francisco. Como se curan los celos. Ed. Ignacio Arellano. Ottawa: Dovehouse, 1991.

. El esclavo en grillos de oro y La piedra filosfal. Ed. Carmen

Díaz Castañon. Oviedo: Caja de Ahorros de Asturias, 1983.

Poesías completas. 2 vols. Madrid: 1722.

. Theatro de los Theatros de los passados y presentes siglos. Ed.

Duncan Moir. London: Tamesis, 1970.

Brown, Jonathan and John Elliot. A Palace for a King: The Buen Retiro and the Court of Philip IV. New Haven: Yale UP, 1980. 
Cascardi, Anthony J. The Limits of Illusion: A Critical Study of Calderón. Cambridge: Cambridge UP, 1984.

García Castañón, Santiago. "La autoridad real en el teatro de Bances Candamo." Looking at the Comedia in the Year of the Quincentennial. Ed. Barbara Mujica, Sharon D. Voros, and Matthew Stroud. Lanham, MD: UP of America, 1993. 229-34.

Greer, Margaret. Introduction. La estatua de Prometeo. By Calderón de la Barca. Kassel: Reichenberger, 1986.

- The Play of Power. Princeton: Princeton UP, 1991.

Hampton, Timothy. Writing from History. The Rhetoric of Exemplarity in Renaissance Literature. Ithaca: Cornell UP, 1990.

Kamen, Henry. Spain in the Later Seventeenth Century, 1665-1700. London: Longman, 1980.

Langdon-Davies, John. Carlos: The King Who Would Not Die. Englewood Cliffs, NJ: Prentice-Hall International, 1963.

Lindenberger, Herbert. Historical Drama. The Relation of Literature and Reality. Chicago: U of Chicago P, 1975.

Lynch, John. The Hispanic World in Crisis and Change. Oxford: Blackwell, 1992.

Martín Vega, Arturo. "Cultura y creación literaria en el último tercio del siglo XVII." El teatro español a fines del siglo XVII. Historia, cultura y teatro en la España de Carlos II. Vol. I. Amsterdam: Rodopi, 1989. 91-109.

Saavedra Fajardo, Diego. Idea de un príncipe político-cristiano. Ed. Vicente García de Diego. 4 vols. Madrid: Espasa Calpe, 1927-30.

Sánchez-Belén, Juan. "La educación del príncipe en el teatro de Bances Candamo." Revista Literaria XLIX.97 (1987): 73-93.

Shklar, Judith N. "Subversive Genealogies." Daedalus 101 (1972): $129-54$.

Streuver, Nancy. The Language of History in the Renaissance. Princeton: Princeton UP, 1970.

Zabaleta, Juan de. El Emperador Commodo. Historia discursiva según el texto de Herodiano. Obras en prosa. Madrid: n. p., 1672. 